\title{
PENGARUH VARIASI LEBAR BILAH BAMBU SUSUNAN HORIZONTAL TERHADAP PERILAKU MEKANIKA BALOK BAMBU LAMINASI YANG MENGALAMI KERUNTUHAN LENTUR
}

\author{
Heru Aji Pradana ${ }^{1}$, Ernawati Sri Sunarsih ${ }^{2}$, Abdul Haris Setiawan ${ }^{2}$ \\ e-mail: herupradana20@gmail.com
}

\begin{abstract}
ABSTRAK: Penelitian bertujuan untuk mengetahui sifat-sifat fisika dan mekanika bambu petung, yaitu kadar air, kerapatan, kuat tarik sejajar serat, kuat tekan sejajar serat, kuat tekan tegak lurus serat, kuat lentur, kuat geser dan modulus elastisitas, mengetahui pengaruh variasi lebar bilah bambu yang disusun horizontal terhadap MOR dan MOE, dan mengetahui nilai MOR dan MOE yang dihasilkan jika dibandingkan dengan kelas kuat kayu. Penelitian menggunakan metode kuantitatif ekperimen dan teknik analisa data menggunakan analisis Regresi linier sederhana. Pengambilan sampel dilakukan dengan sampling jenuh yaitu sebanyak 9 sampel,masing-masing variasi terdiri dari 3 sampel. Hasil penelitian menunjukkan bahwa, hasil uji sifat fisika dan mekanika bambu petung sesuai dengan sifat fisika dan mekanika yang terdapat pada kayu kelas kuat II. Kuat lentur balok laminasi susunan bilah horizontal dengan variasi lebar bilah $10 \mathrm{~mm}, 15 \mathrm{~mm}$ dan $20 \mathrm{~mm}$ berpengaruh signifikan terhadap nilai MOR yang dihasilkan. Semakin besar lebar bilah bambu yang digunakan maka semakin besar nilai MOR yang didapatkan. Namun tidak berpengaruh signifikan terhadap nilai MOE yang dihasilkan. Nilai MOR dan MOE ratarata balok bambu laminasi susunan horizontal termasuk kelas kuat kayu I.
\end{abstract}

Kata kunci : variasi lebar bilah, sifat fisika dan mekanika, MOR dan MOE.

\footnotetext{
${ }^{1}$ Mahasiswa Program Studi Pendidikan Teknik Bangunan FKIP Universitas Sebelas Maret

${ }^{2}$ Pengajar Program Studi Pendidikan Teknik Bangunan FKIP Universitas Sebelas Maret
} 


\title{
INFLUENCE OF VARIATION BLADE WIDE OF BAMBOO HORIZONTAL STRUCTURE ON MECHANICAL BEHAVIOR OF BEAMS BAMBOO LAMINATION WHO HAVE A LOWEN CROSS
}

\author{
Heru Aji Pradana ${ }^{1}$, Ernawati Sri Sunarsih ${ }^{2}$, Abdul Haris Setiawan ${ }^{2}$ \\ e-mail: herupradana20@gmail.com
}

\begin{abstract}
The study aims to determine the physical properties and mechanics of petung bamboo, namely moisture content, density, tensile strength parallel to the fiber, compressive strength parallel to the fiber, perpendicular compressive strength of the fiber, flexural strength, shear strength and modulus of elasticity, knowing the effect of variations in the width of the bamboo slats which are arranged horizontally against $M O R$ and MOE, and know the MOR and MOE values produced when compared to the strong wood class. Research uses quantitative experimental methods and data analysis techniques using simple linear regression analysis. Sampling is done by saturated sampling, which is 9 samples, each variation consists of 3 samples. The results showed that the results of the physical properties and mechanics of petung bamboo test were in accordance with the physical and mechanical properties found in strong class II wood. The flexural strength of laminated beams in the horizontal bar arrangement with variations in blade width of $10 \mathrm{~mm}, 15 \mathrm{~mm}$ and $20 \mathrm{~mm}$ has a significant effect on the value of the MOR produced. The greater the width of the bamboo bar used, the greater the MOR value obtained. But there is no significant effect on the value of the MOE generated. The average MOR and MOE values of horizontal arrangement bamboo laminated beams include strong wood class I.
\end{abstract}

Keywords: Variation of blade width, physical and mechanical properties, MOR and MOE.

\footnotetext{
${ }^{1}$ Student of Civil Engineering On Faculty of Teacher Training and Education Sebelas Maret University

${ }^{2}$ Lecture of Civil Engineering On Faculty of Teacher Training and Education Sebelas Maret University
} 


\section{PENDAHULUAN}

Bambu merupakan tanaman sebangsa rumput yang banyak tumbuh dinegara kita. Tanaman ini dapat tumbuh di daerah beriklim panas maupun dingin. Kebanyakan didaerah pedesaan tanaman bambu dibiarkan tumbuh liar, akan tetapi walaupun tidak mendapatkan perawatan, bambu dapat tumbuh dengan baik. Bambu tumbuh secara bergerombol membentuk rumpun, tunas-tunas muda keluar dari rimpang dan membentuk tanaman baru (Monalisa Manuputty dkk, 2010:789).

Dari seluruh tanaman yang dikenal di Indonesia, bambu mempunyai pertumbuhan yang sangat cepat. Jenis tertentu dari bambu bahkan dapat tumbuh $5 \mathrm{~cm}$ per jam atau $120 \mathrm{~cm}$ per hari. Berbeda dengan kayu yang baru siap di tebang dengan kualitas baik setelah umur 40-50 tahun. Bambu dengan kualitas baik dapat diperoleh dalam umur 3-5 tahun (Tedy Wonlele dkk, 2013:2).

Kekuatan tarik dari bambu sendiri cukup tinggi dan dapat mencapai angka $370 \mathrm{MPa}$, sehingga dapat dijadikan sebagai bahan pengganti baja dalam aplikasi beban tarik. Selain ringan, kuat, ulet, rata, fleksibel, dan mudah dikerjakan, bambu mempunyai dinding tipis yang dibagi menjadi ruasruas yang memberikan kekuatan besar pada bambu sehingga baik untuk dijadikan sebagai bahan konstruksi.

$$
\text { Pesatnya }
$$

perkembangan

teknologi membuat bambu dapat diolah sedemikian rupa sehingga dapat dimanfaatkan dalam berbagai hal, dan salah satu pengolahannya yaitu dengan cara laminasi. Balok laminasi (glue laminated) diperkenalkan di Eropa pada akhir abad ke-19 yang berupa penggabungan beberapa lapisan kayu gergajian dengan resin tertentu.
Teknologi ini sejatinya adalah teknik penggabungan bahan-bahan yang berdimensi kecil menjadi bahan yang berdimensi lebih besar baik panjang, lebar maupun tebalnya. Dan teknik ini dapat diterapkan untuk membentuk bambu menjadi bahan konstruksi bangunan.

Balok laminasi dibedakan menjadi dua yaitu balok laminasi horizontal dan balok laminasi vertikal. Balok laminasi horizontal didesain untuk menahan beban lentur arah tegak lurus lebar permukaan papan lapisan. Sedangkan balok laminasi vertikal adalah balok laminasi yang didesain untuk menahan beban lentur yang berarah sejajar bidang lebar papan lapisan.

Penelitian ini pada dasarnya merupakan upaya untuk mengetahui sifat fisika dan mekanika bambu petung, mengetahui pengaruh variasi lebar bilah terhadap MOR dan MOE, serta untuk mengetahui nilai MOR dan MOE yang dihasilkan jika dibandingkan dengan kelas kuat kayu.

\section{Bambu}

Menurut Morisco (2005) dalam Purnawan Gunawan (2007:14) bambu merupakan jenis tanaman rumputrumputan (Famili Graminae) yang tumbuh hampir di seluruh dunia, terutama di benua Afrika, Amerika, Asia dan Australia. Saat ini telah diketahui sebanyak 50 negara yang terurai kedalam 700 jenis bambu.

Bambu memiliki banyak kelebihan, diantaranya adalah:

a) Mempunyai pertumbuhan yang cepat.

b) Mempunyai kuat lentur dan elastisitas yang tinggi.

c) Memiliki berat jenis rendah

d) Mudah dikerjakan. 
e) Memiliki ruas-ruas yang memberi kekuatan besar pada bambu.

Sifat fisika dan mekanika bambu petung terdiri dari: kadar air, kerapatan, kuat tarik sejajar serat, kuat tekan tegak lurus, kuat tekan sejajar serat, kuat geser sejajar serat, kuat lentur dan modulus elastisitas (Purnawan Gunawan, 2007:14).

\section{Balok Laminasi}

Teknologi laminasi merupakan salah satu alternatif cara pengolahan bambu yang relevan untuk mencapai tujuan yang diharapkan. Dalam penerapan teknologi laminasi dapat diperoleh dimensi struktur baik panjang, lebar maupun tebal yang lebih besar sesuai yang diinginkan (Gusti Made Oka, 2008:95).

Balok laminasi memiliki banyak kelebihan, diantaranya adalah:

a) Ukuran dapat dibuat lebih besar, baik panjang, lebar, maupun tingginya.

b) Dapat mengurangi reduksi kekuatan oleh cacat bambu.

c) Konfigurasi bentuk lonjong dapat dipabrikasi dengan mudah.

d) Menghasilkan kekuatan yang lebih besar dibandingkan lapisan tunggal.

Dalam proses pembuatan laminasi dengan perekat (glue laminated), selain harus memperhatikan sifat kayu dan bambu, harus diperhatikan pula jenis perekat yang digunakan. Karena perekat juga akan menentukan hasil dari kayu dan bambu laminasi tesebut (Widodo dkk, 2004:264).

\section{MOR dan MOE}

Kekuatan balok sangat dipengaruhi oleh hubungan antara tegangan tekan dan tegangan tarik arah sejajar serat. Tegangan lentur maksimum yang terjadi disebut MOR. Nilai MOE atau modulus elastisitas adalah ukuran ketahanan balok terhadap perpanjangan bila mengalami tarik atau tekan selama proses pembebanan berlangsung secara konstan (Rina Sarikusuma, 2010:24).

\section{METODE PENELITIAN}

Sampel yang digunakan sebanyak 3 sampel pada setiap variasi untuk masing-masing pengujian dengan jenis bambu adalah bambu petung. Bambu petung diambil dari Kabupaten Purworejo pada umur 3-4 tahun. Bambu dibuat bilahan dengan variasi lebar $1 \mathrm{~cm}$, $1,5 \mathrm{~cm}$, dan $2 \mathrm{~cm}$ dengan susunan bilah horizontal. Total sampel yang digunakan adalah 9 sampel.

Dalam meningkatkan daya tahan bambu terhadap kerusakan akibat serangga atau pun akibat pengaruh luar lainnya maka diperlukan bahan pengawet untuk mengantisipasi terjadinya kerusakan pada bambu. Metode yang dilakukan dalam proses pengawetan bambu ada yang dengan cara alami ada pula yang kimia.

Perekat yang digunakan adalah lem presto DN berkapasitas 4000 gram. Penelitian ini menggunakan tekanan kempa menurut standar dari lem yang digunakan yaitu 1,75 $\mathrm{MPa}$ dengan panjang bilah yang digunakan $300 \mathrm{~cm}$ yang sudah dibersihkan kulit luarnya.

Pengujian pada penelitian ini adalah uji lentur berdasarkan ISO 31291975 (E). Kondisi pembebanan balok laminasi menggunakan pembebanan pada dua titik dengan bentang $1 / 3 \mathrm{~L}$, seperti yang tertera pada Gambar 1.

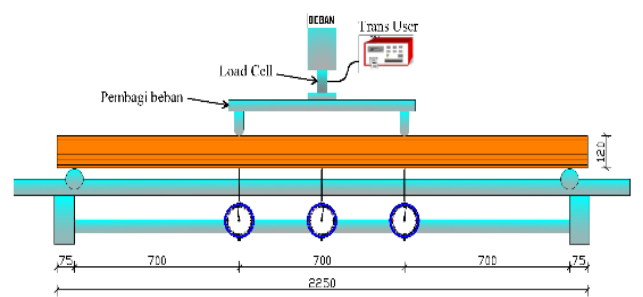

Gambar 1. Pembebanan Balok 2 titik 
Teknik pengambilan sampel adalah dengan sampling jenuh dimana seluruh anggota populasi sebagai sampel dengan variabel bebas berupa variasi lebar bilah bambu yaitu $1 \mathrm{~cm}, 1,5 \mathrm{~cm}$, dan $2 \mathrm{~cm}$, variasi lebar bilah di tunjukan pada Gambar 2.

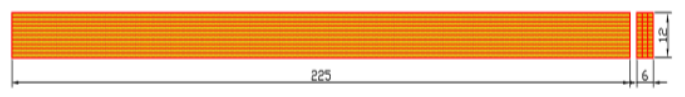

(1)
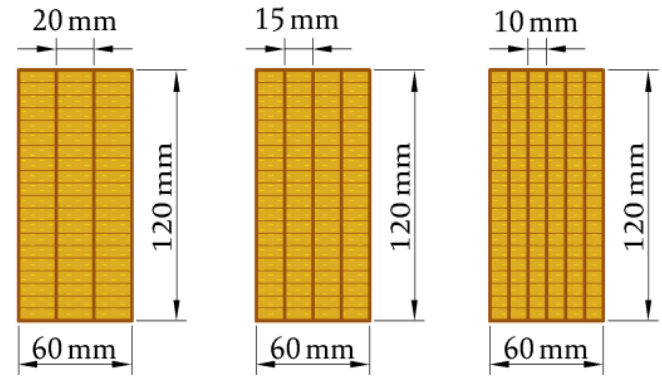

(2)

Gambar 2. Benda Uji (1) balok laminasi, (2) variasi lebar bilah

Analisa data yang digunakan untuk mengetahui pengaruh variasi lebar bilah terhadap MOR dan MOE yaitu dengan menggunakan analisis regresi linier sederhana.

Tabel 1. Hasil Pengujian Sifat Fisika dan Mekanika

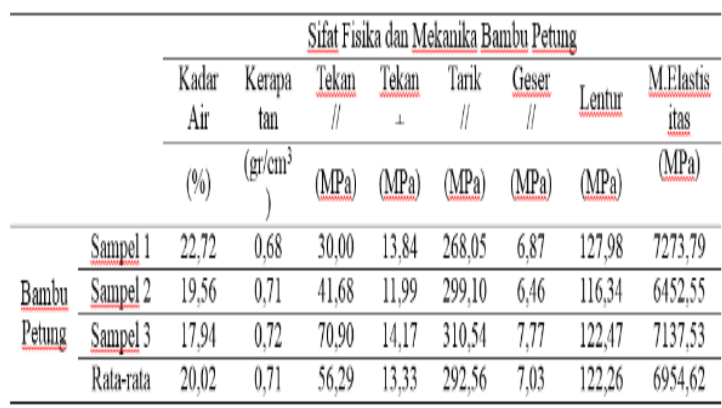

Dari Tabel 1 diatas dapat disimpulkan bahwa sifat fisika dan mekanika bambu petung sesuai dengan kayu kelas kuat II menurut PKKI NI-05 1961 dan E26 menurut SNI-05 2002.
Sifat mekanika yang terlihat mencolok adalah pada kekuatan tarik dan lentur dari bambu petung yang lebih besar bila dibandingkan dengan kayu. Hal ini terjadi karena susunan arah serat pada bambu yang sejajar, dan ini memungkinkan bambu untuk dapat menahan lendutan yang lebih besar. Bambu pempunyai fleksibilitas yang baik dan berbentuk dinding- dinding tipis yang dibagi menjadi ruas-ruas yang memberikan kekuatan besar, tipis yang

\section{HASIL DAN PEMBAHASAN \\ 1. Pengujian Sifat Fisika dan Mekanika}

Pemeriksaan dan pengujian bahan dasar bambu petung dilakukan untuk mengetahui karakteristik bahan yang digunakan. Hasil pengujian kemudian dibandingkan dengan kelas kuat kayu menurut standar SNI-05 2002 dan PKKI NI-5 1961.

Pengujian yang dilakukan meliputi pengujian sifat fisika yaitu kadar air dan kerapatan sedangkan uji sifat mekanika yaitu kuat tekan sejajar serat, kuat tekan tegak lurus serat, kuat tarik, kuat geser sejajar serat, kuat lentur dan kuat geser sejajar serat bambu. Adapun hasil pengujian sifat fisika dan mekanika bambu petung disajikan dalam Tabel 1. dibagi menjadi ruas-ruas yang memberikan kekuatan besar, selain itu bambu juga mempunyai serat yang kuat sehingga mampu menahan gaya lentur yang cukup besar. Namun tidak setiap jenis bambu mempunyai kekuatan yang sama.

\section{Pengaruh Lebar Bilah Terhadap Keruntuhan Lentur}

Hasil pengujian kuat lentur balok bambu laminasi dengan variasi lebar bilah $1 \mathrm{~cm}, 1,5 \mathrm{~cm}$, dan $2 \mathrm{~cm}$ terhadap MOR (modulus of rapture) dapat dilihat pada Gambar 3. 


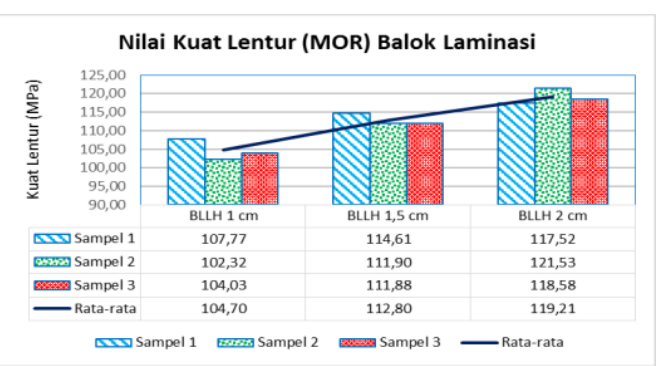

Gambar 3. Hasil Pengujian Kuat Lentur (MOR) Balok Laminasi

Dari Gambar 3 dapat disimpulkan bahwa terdapat pengaruh signifikan untuk variasi lebar bilah bambu susunan horizontal dengan variasi $1 \mathrm{~cm}, 1,5 \mathrm{~cm}, 2 \mathrm{~cm}$ terhadap Modulus of Rapture (MOR). Semakin lebar bilah bambu yang digunakan semakin besar nilai MOR yang didapatkan.

Hal yang menyebabkan terjadinya peningkatan kekuatan adalah bahwasannya semakin lebar bilah yang digunakan maka semakin besar pula luasan permukaannya. Dan ketika bilahbilah tersebut dijadikan balok laminasi maka jumlah spasi yang ada dalam balok tersebut semakin sedikit, sehingga kesolidan dari balok bambu laminasi lebih tinggi dan kekuatan lentur rata-rata yang dihasilkan pada variasi lebar bilah $2 \mathrm{~cm}$ pun cukup tinggi yaitu sebesar 119,21 MPa.

Berbeda dengan balok laminasi dengan lebar bilah yang kecil, semakin kecil lebar bilah maka semakin kecil pula luas permukaannya. Dan ketika bilah dengan lebar kecil digunakan untuk membuat balok laminasi, maka spasi yang dihasilkan semakin banyak, begitu pula lem yang digunakan. Hal tersebut membuat kesolidan balok menjadi berkurang sehingga kekuatan lentur ratarata yang dihasilkan dari pengujian balok bambu laminasi untuk variasi lebar bilah $1 \mathrm{~cm}$ sebesar 104,70 MPa.

Hasil pengujian kuat lentur balok bambu laminasi dengan variasi lebar bilah $1 \mathrm{~cm}, 1,5 \mathrm{~cm}$, dan $2 \mathrm{~cm}$ terhadap MOE (modulus of elasticity) dapat dilihat pada Gambar 4.

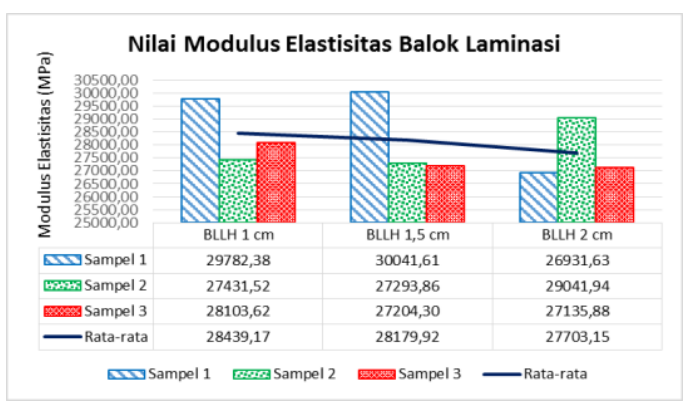

Gambar 4. Hasil Pengujian Modulus

Elastisitas (MOE) Balok Laminasi

Dari Gambar 4 dapat disimpulkan bahwa tidak terdapat pengaruh signifikan untuk variasi lebar bilah bambu susunan horizontal dengan variasi $1 \mathrm{~cm}, 1.5 \mathrm{~cm}$, dan $2 \mathrm{~cm}$. Nilai MOE tidak mengalami perubahan yang signifikan terhadap pertambahan lebar bilah bambu.

Hal yang mempengaruhi besar kecilnya nilai MOE adalah nilai kekakuan, dimana nilai kekakuan sendiri adalah perbandingan antara beban proporsional dan lendutan proporsional. Artinya semakin besar beban yang diterima, maka semakin besar nilai MOE. Namun semakin besar lendutan, maka semakin kecil nilai MOE yang didapat.

Berdasarkan penelitian yang telah dilakukan oleh Wijaya (1995) dalam Rina Sarikusuma (2010) terhadap dua jenis bambu yaitu bambu ori dan petung, menunjukan bahwa jenis bambu mempengaruhi tingkat kekuatan dari balok laminasi sehingga tidak berarti satu jenis bambu memiliki kekuatan yang lebih tinggi secara keseluruhan dari jenis bambu lainnya. Kekuatan tarik 
akan lebih dipengaruhi oleh jumlah ruas, kekuatan tekan akan lebih dipengaruhi oleh jenis bambu yang digunakan, kekuatan lentur akan dipengaruhi oleh jenis bambu yang digunakan sedangkan kekuatan geser dipengaruhi oleh jumlah perekat terlabur.

Bambu petung yang dibuat menjadi balok laminasi memang mempunyai kekuatan lentur yang lebih besar bila dibandingkan dengan bambu petung dalam kondisi utuh, dan ini merupakan sebuah penemuan besar yang dapat diaplikasikan sebagai bahan alternatif pengganti kayu sebagai bahan bangunan. Balok bambu laminasi selain masuk di kelas kuat kayu satu juga mempunyai sifat elastisitas yang baik

Tabel 2. Hasil uii MOR dan MOE

\begin{tabular}{|c|c|c|c|c|c|c|c|}
\hline \multirow[b]{2}{*}{ Kode Balok } & \multicolumn{3}{|c|}{ Dimentsi } & \multirow{2}{*}{$\begin{array}{l}\text { P. maks } \\
\text { (KN) }\end{array}$} & \multirow{2}{*}{$\begin{array}{c}\text { Iendutan } \\
\text { (mm) }\end{array}$} & \multirow{2}{*}{$\frac{M(R)}{\left(M P_{A}\right)}$} & \multirow{2}{*}{$\frac{M(D)}{(M P a)}$} \\
\hline & $\begin{array}{l}\text { Panjang } \\
(\mathrm{mm})\end{array}$ & $\begin{array}{l}\text { Letar } \\
\text { (mim) }\end{array}$ & $\begin{array}{l}\text { lingef } \\
(\mathrm{mm})\end{array}$ & & & & \\
\hline||$l \mid c m$ & 2100 & 60 & 120 & 21,53 & 28,74 & 10,70 & 284399,17 \\
\hline 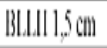 & 2100 & 60) & 120 & 23,16 & 31.55 & 112,80 & 28179,92 \\
\hline BLIH2 cm & 2100 & 60 & 120 & 25,06 & 33,60 & $\mid 10,21$ & 27703,15 \\
\hline
\end{tabular}

Dari Tabel 2 dapat disimpulkan bahwa sesuai peraturan SNI-05 2002 nilai MOR dan MOE yang dihasilkan dari balok bambu laminasi susunan horizontal termasuk dalam klasifikasi kelas kuat E26, sedangkan sesuai peraturan PKKI NI-5 1961 nilai MOR dan MOE rata-rata balok bambu laminasi susunan horizontal termasuk dalam klasifikasi kelas kuat kayu I.

Hal tersebut terjadi karena bambu yang digunakan yaitu bambu petung dengan kualitas baik, selain itu bilah yang digunakan sudah dibersihkan kulitnya, sehingga daya rekatnya lebih baik daripada bilah yang masih berkulit.

Kuat lentur balok laminasi ditunjukan dengan nilai MOR dan MOE. Nilai MOR dipengaruhi oleh besarnya momen, dan momen inersia dari balok tersebut. Nilai MOE dipengaruhi oleh lendutan, besarnya beban, bentang, jarak tumpuan ke beban dan momen inersia balok laminasi sehingga dapat menjadi salah satu produk unggulan.

\section{Nilai MOR dan MOE Terhadap Kelas Kuat Kayu}

Hasil pengujian kuat lentur balok bambu laminasi dengan variasi lebar bilah $1 \mathrm{~cm}, 1,5 \mathrm{~cm}$, dan $2 \mathrm{~cm}$ terhadap kelas kuat kayu menurut PKKI NI-05 1961 dan menurut SNI-05 2002 dapat dilihat pada Tabel 2.

\section{SIMPULAN}

Berdasarkan hasil pengujian dan pembahasan yang telah dilakukan, maka dapat diambil kesimpulan sebagai berikut:

1. Hasil uji sifat fisika dan mekanika bambu petung sesuai dengan sifat fisika dan mekanika yang terdapat pada kayu kelas kuat II.

2. Hasil uji kekuatan lentur balok bambu laminasi dengan variasi lebar bilah 1 $\mathrm{cm}, 1,5 \mathrm{~cm}, 2 \mathrm{~cm}$ terdapat pengaruh signifikan terhadap nilai MOR yang dihasilkan. Semakin besar lebar bilah bambu yang digunakan maka semakin besar nilai MOR yang didapatkan. Namun tidak berpengaruh signifikan terhadap nilai MOE yang dihasilkan.

3. Nilai MOR dan MOE rata-rata balok bambu laminasi susunan horizontal termasuk kelas kuat kayu I.

\section{SARAN}

Berdasarkan simpulan, maka
dapat dikemukakan saran sebagai berikut:

1. Perlu adanya metode pembuatan balok bambu laminasi yang lebih efektif, sehingga proses pengerjaan tidak terlalu lama. 
2. Perlu dilakukan sosialisasi pemanfaatan balok bambu laminasi sebagai bahan bangunan alternatif pengganti kayu kepada masyarakat luas.

3. Perlu adanya penelitian teknologi laminasi dengan meninjau aspek ekonomi.

\section{DAFTAR PUSTAKA}

Anonim. (2006). Peraturan Konstruksi Kayu Indonesia NI-5 PKKI1961.Bandung:Yayasan

Penyelidikan Masalah Bangunan.

Gunawan, P. (2007). Pengaruh Jenis Perekat Terhadap Keruntuhan Lentur Balok Laminasi Galar dan Bilah Vertikal Bambu Petung.Media Teknik Sipil: 13-20.

International Organization for Standardization. (2004). ISO 3129-1975 (E) : Pengujian Kuat Lentur. International Organization for Standardization.

Manuputi, M. \& Berhitu, P.T. (2010). Pemanfaatan Material Bambu Sebagai Alternatif Bahan Komposit Pembuatan Kulit Kapal Pengganti Material Kayu untuk Armada Kapal Rakyat yang Beroperasi Di Daerah Maluku. Jurnal Teknologi 7 (2): 788-794.

Mustafa, S. (2012). Karakteristik Sifat Fisika dan Mekanika Bambu Petung Pada Bambu Muda, Dewasa dan Tua (Studi Kasus: Bagian Pangkal).

Oka, G.M. (2008). Analisis Arah Laminasi Vertikal dan Horizontal Terhadap Perilaku Lentur Balok Bambu Laminasi. Jurnal SMARTek 6 (2): 94-103.
Sarikusuma, R. (2010). Model Susunan Bilah Bambu Vertikal Antara Sisi Bilah yang Sama Terhadap Keruntuhan Lentur.

Standar Nasional Indonesia. (2002). SNI-05-2002 : Tata Cara Perencanaan Konstruksi Kayu Indonesia. Badan Standarisasi Nasional.

Wonlele, T., Dewi, S.M., \& Nurlina, S. (2013). Penerapan Bambu Sebagai Tulangan Dalam Struktur Rangka Batang Beton Bertulang. Jurnal Rekayasa Sipil, 7 (1): 1-12.

Widodo, A.B., Widjaja, s., \& Rosyid D.M.(2004). Pengembangan Komposit Kayu dan Bambu Sebagai Material Alternatif Untuk Pembangunan Kapal Kayu. Prosiding Pertemuan Ilmiah Ilmu Pengetahuan dan Teknologi Bahan 2004 Serpong. 262-274. 